\title{
Paulina Codogni
}

\section{The Architecture of Separation: Israeli Policy towards the Palestinians in the West Bank}

DOI 10.35757/CIV.2016.19.09

History tells us to appreciate the contribution of architecture and its creators to the past and the contemporary shape of the world. Architecture, even more than politics and the art of war, is held to create the material space for the functioning of people and to support the activities that change the fate of nations and political communities. Not only does this require the knowledge and ingenuity of an architect, but also the collaboration of a good team.

It is of particular importance that architects are rational and know the purpose of their action. In his well-known work entitled The Ten Books on Architecture, Vitruvius writes that the question of approving any work may be considered under three heads: that is, delicacy of workmanship, sumptuousness, and

Paulina Codogni - is a Doctor of Political Science, the author of books about contemporary Polish history, a deputy rector for international cooperation at Collegium Civitas and an assistant professor in the Department of Central and Eastern Europe at the Institute of Political Studies of the Polish Academy of Science. Her research interests include the period of political transformation in Poland and civil resistance. She is the author of the monographs: The Year 1956 (2006), The Round Table - the Polish Rubicon (2009) and The Elections in June 1989 - at the Threshold of Political Transformation (2012). Further effects of the wall on the West Bank will be discussed in the forthcoming monograph on Israeli policy towards the Palestinians in the West Bank. 
design'. In this work, which dates back to the period between 20 and 10 BC, i.e. the reign of Emperor Augustus, Vitruvius argues that an architect should possess comprehensive knowledge allowing for flawless execution of his duties. In his opinion, medicine is one of the disciplines that the architect should master. A city should be built in a healthy environment, and this should be ensured by the architect. Vitruvius suggests that the healthfulness of a proposed site should be checked by examining the livers of sacrificial animals, such as cows, sheep, and pigs, which take their food and water from the same sources that the inhabitants of the future city would use $\mathrm{e}^{2}$. The author even pays attention to possible draughts and their adverse effects on human health. For this reason, he recommends that special attention should be paid to the location of theatres and forums so that the audience, focused on the show, would not be exposed to wind and sunburn ${ }^{3}$. According to Vitruvius, it is the architect's duty to consider all sorts of inconveniences and be aware that his decisions directly affect those who are going to live in the environment created by him.

Similar importance was attributed to the profession of the architect during the Renaissance. Leon Battista Alberti, one of the most outstanding figures of this period and the author of the second best-known work on architecture and the art of construction after that by Vitruvius, wrote:

It is my view moreover that, should you question all the various cities which within human memory have fallen into enemy hands by siege, and inquire who defeated and conquered them, they would not deny that it was the architect; and that they could easily have scorned an enemy armed with weapons alone but could no longer have resisted the power of invention, the bulk of war machines and the force of ballistic engines, with which the architect had harassed, oppressed, and overwhelmed them. On the other hand, those besieged would consider no protection

\footnotetext{
1 Vitruvius, The Ten Books on Architecture, translated by Morris Hicky Morgan, New York: Dover Publications, Inc., 1960, p. 192.

2 Ibidem, p. 20.

3 Ibidem, p. 131.
} 
better than the ingenuity and skill of the architect. Should you examine the various military campaigns undertaken, you would perhaps discover that the skill and ability of the architect have been responsible for more victories than have the command and foresight of any general; and that the enemy were more often overcome by the ingenuity of the first without the other's weapons, than by the latter's sword without the former's good counsel. And what is more important, the architect achieves his victory with but a handful of men and without loss of life. So much for the use of architecture ${ }^{4}$.

This quotation comes from the period when architects were also responsible for the construction of war machines. Alberti portrays the struggle for a city as a duel of two architects, one being the creator of the city and the other the developer of ballistic machines.

This classic view of the role of the architect and the specific nature of this discipline has not fundamentally changed up until the present time. This is evident in the statement of Filip Springer, a contemporary architecture researcher, who says that 'architects create our living spaces. Owing to their works, our existence is to become either only bearable or even enjoyable. They have received great power, they determine our quality of life - this is their only reward and their only responsibility ${ }^{5}$.

Alvar Aalto, a Finnish architect, has a similar opinion:

Architecture has an unstated ideal, which is to recreate paradise. If we did not constantly bear this idea in mind, all of our buildings would be simpler and more trivial, and life would become... yes, it would almost no longer be worth living. Every building, every product worthy of the art of building wants to prove that we want to create a paradise on earth for mankind ${ }^{6}$.

It can be seen that the understanding of the essence of architecture remains unchanged, though marked by the experience

\footnotetext{
4 L.B. Alberti, On the Art of Building in Ten Books, Cambridge: MIT Press, 1988, p. 4.

5 F. Springer, Księga zachwytów, Agora, Warszawa 2016, p. 10 (my translation).

6 Valode\& Pistre, Architektura współczesna istota i powierzchowność, [in:] A. Budak (ed.), "Co to jest architektura”, Bunkier Sztuki, Krakow, 2002, s. 350 (my translation).
} 
of generations: architecture means creating useful works that provide us with pleasant experiences and are tailored to our needs. Today, we say that the task of architecture is to create order in the environment to meet the physical, material and cultural needs of people. To achieve this goal, architects introduce changes to the environment through the construction of new forms and space divisions for a variety of purposes. In other words, architecture is the entire space that surrounds a human being, who has created and organized this space. 'It is the reflection of the functioning of the political, social, and economic system; in other words, architecture reflects the way of governing the state: who governs and how they do it' ${ }^{7}$. Architecture is thus expected to cope with and at the same time reflect economic and social changes, respond to current conditions and predict the future so as to meet the needs of a society.

Can architecture be perceived in a different way? Perhaps we should also consider other definitions of architecture and its tasks. In fact, architecture is sometimes also used to create structures that are tools for spatial and social engineering, dictated by the desire to separate one group from another. The trend has been mentioned by Renzo Piano, an eminent Italian architect and the creator of the Pompidou Centre. In an extended interview, he says:

But it [architecture] is also a socially dangerous art, because it is an imposed art. You can put down a bad book; you can avoid listening to bad music; but you cannot miss the ugly tower block opposite your house. Architecture imposes total immersion in ugliness; it does not give the user a chance. And this is a serious responsibility-for now and for future generations ${ }^{8}$.

Piano mainly expresses his fear that architecture may spoil the taste and the aesthetic sensibility of people, but he also notes

\footnotetext{
7 J. Włodarczyk, Obecność architektury, Wyższa Szkoła Techniczna w Katowicach, Katowice 2013, p. 46, 19 (my translation).

8 R. Piano, Acceptance Speech, http://www.pritzkerprize.com/1998/acceptance-speech (accessed on 06 February 2017).
} 
that it can shape human attitudes by enforcing its impact on them. A man can be enslaved by an imposed canon of beauty and ugliness, as well as by the non-functional, non-progressive arrangement of space in which he comes to live. Architecture can therefore be a tool of power and even an element of ideology.

What Piano says about the shaping of attitudes can be compared with a statement by Adolf Loos, an Austrian architect. In his essay, he writes that:

Architecture arouses moods in people, so the task of the architect is to give these moods concrete expression. A room must look cosy, a house comfortable to live in. To secret vice the law courts must seem to make a threatening gesture. A bank must say, 'Here your money is safe in the hands of honest people'.

However, some architectural objects can carry more than just one message or they even have two opposite semantic dimensions and therefore trigger completely different emotions. The examples of such objects are those that stand on the borderlands and have been imposed on one community by another. A case in point is the West Bank Wall that separates the Palestinians from Israel ${ }^{10}$.

The decision to build this barrier was taken by the government of General Ariel Sharon in 2002 after the upsurge of suicide attacks by Palestinians on Israeli civilians ${ }^{11}$. The state was unable to suppress these attacks, even though it conducted brutal

\footnotetext{
9 A. Loos, Ornament and Crime: Selected Essays, Riverside, Ariadne 1998, p. 84.

${ }^{10}$ The West Bank is a piece of land shaped like a butterfly wing and located between Israel and Jordan. It is $128 \mathrm{~km}$ long and between 46 and 90 kilometres wide at its broadest point. It is inhabited by 2.5 million Palestinians and more than half a million Jewish settlers. Before the state of Israel was created in 1948, the territory had been a part of historic Palestine. It was under Jordanian rule from 1948 to 1967. After Israel won the Six-Day War in 1967, it became the occupied territory of Israel, even though the Israeli authorities claim that they only administer this area. For decades, the Palestinians have been fighting for independence through armed struggle and social resistance. Many hoped that the conflict would be solved by peace negotiations, including the Oslo Agreements signed in the early 1990s, but they did not bring a lasting solution and have worsened the situation of the Palestinian population.

${ }^{11}$ Following the terminology used by the International Tribunal of Justice, in this text most often use the term "wall", replacing it occasionally (depending on context) by "fence" or "barier".
} 
attacks on civilians, introduced curfews, demolished the houses and neighbourhoods of the perpetrators and used all range of collective punishment. Sharon made the controversial decision to build the wall due to the growing number of Palestinians in the West Bank.

General Amos Yaron, the Director General of the Israel Ministry of Defence, described the wall as follows:

It is an effective way to significantly reduce the penetrative capabilities of Palestinians who come to commit terrorist attacks inside the State of Israel .... it is a very effective way to prevent terrorists from committing their crimes inside Israeli territory. This is the primary reason behind this investment. The secondary reason is that for many years the Palestinians considered Israel to be an unlimited resource for stolen goods, especially cars and agricultural equipment... The rates of theft and burglary have risen drastically ${ }^{12}$.

By the decision of the Israeli authorities, the barrier began to be erected along the so-called Green Line, which was 315 kilometres long. It was marked green on the map after the 1948 War of Independence ${ }^{13}$. Although theoretically the wall runs along the Green Line, almost $85 \%$ of it encroaches into the West Bank, which means that once completed, almost $10 \%$ of its territory, including East Jerusalem, will remain on the Israeli side ${ }^{14}$. By designating such a course for the wall, Israeli architects have incorporated the biggest Jewish settlements that emerged in the West Bank after 1967 into Israel. Due to deviations from the straight line, the Green Line has a sinuous shape in many places and thus its planned length is calculated to be 708 kilometres $^{15}$.

Along most of its length, the barrier takes the form of a network of electric fences, reinforced with barbed wire and equipped with

\footnotetext{
${ }^{12}$ Wall, directed by Simon Bitton, France-Israel, 2004.

${ }^{13}$ It separated Israel from Jordan's West Bank, which was captured by Israel in 1967 during the so-called Six-Day War.

${ }^{14}$ United Nations Office for the Coordination of Humanitarian Affairs occupied Palestinian territory, Humanitarian Atlas, December 2011, p. 26, https://www.ochaopt.org/documents / ocha_opt_humaitarian_atlas_dec_2012_web.pdf (25 VI 2016).

${ }^{15}$ Ibidem.
} 
cameras, radars, and sensors. Any attempt to cut or even touch it activates an alert and soldiers arrive at the scene within a few minutes. Additional elements such as watchtowers and sniper posts have been placed along the fence. An asphalt road runs along the entire length of the barrier allowing patrols to move quickly, and the surrounding area is covered with sand to enable the footprints of those who have illegally crossed the fence to be traced. Because of all these elements, the whole structure is between 30-70 metres to 100 metres wide.

This describes what the barrier usually looks out in the open, far from towns and villages. In other places, however, where it was difficult to demarcate a space half a metre wide between the walls, Israeli planners decided to erect a concrete wall, which is between 6 and 8 metres high. The Palestinians living in the shadow of the wall often emphasize that it is twice as high as the Berlin Wall ${ }^{16}$.

Due to the variety of materials used to erect the wall, it is difficult to choose the most appropriate name for it. In its 2004 verdict, which stated that the wall had been unlawfully erected, the International Court of Justice used the word wall. This word is also most often used in this paper, however, occasionally words barrier and fence are used interchangeably.

The design of the wall included a number of passes to enable communication between the two sides. In 2016, more than 70 gates were placed in the wall, nearly half of which were closed and used exclusively for military purposes. Just a few gates were open throughout the day, but closed at night, and the other so-called agricultural gates were only open during the olive and cereal harvesting season, or three times a day. While the former were situated close to major population centres, for example, near Jerusalem, the latter were usually located in less populated areas.

\footnotetext{
${ }^{16}$ As of $2011,61 \mathrm{~km}$ of the then barrier consisted of a concrete wall, the longest sections of which were located in densely populated areas, i.e. in Jerusalem, Bethlehem, Qalqilya and Tulkarm. Barrier Update, Special Focus, July 2011, OCHA, p. 4, http://www.ochaopt.org/ documents/ocha_opt_Barrier_update_july_2011_english.pdf (10 VI 2016).
} 


\section{S I}

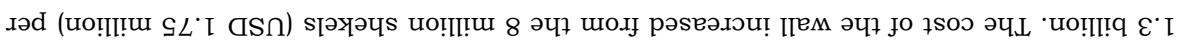

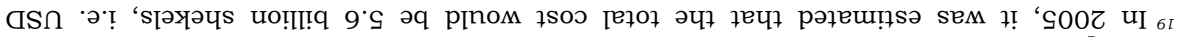
'LSI d ' $\angle 00 Z$

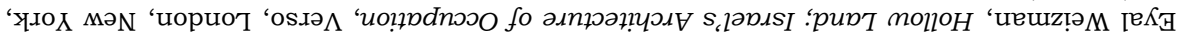

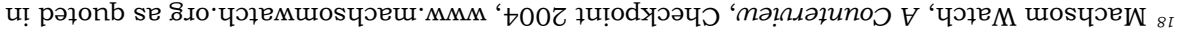

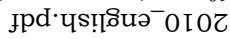

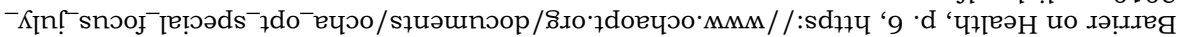

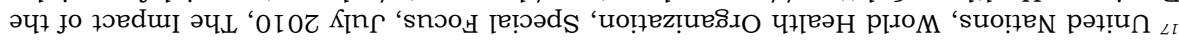

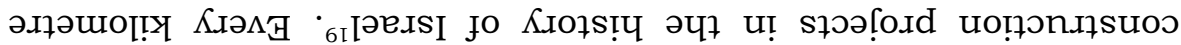

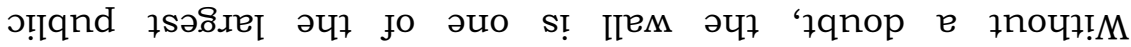

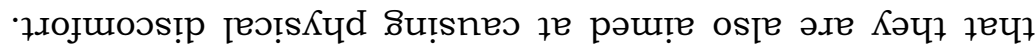

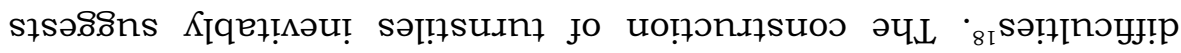

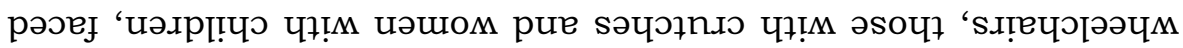
u! әsoчł Кโ[

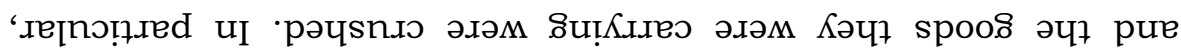

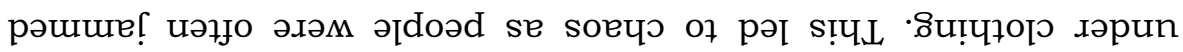

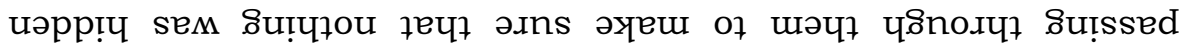

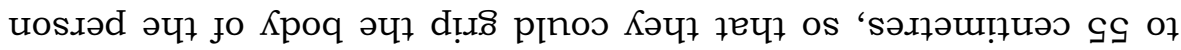

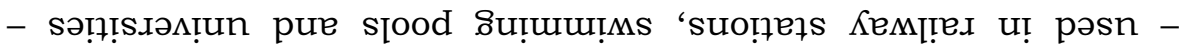

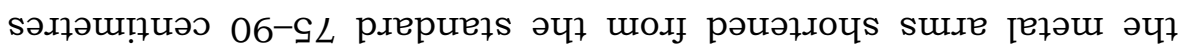

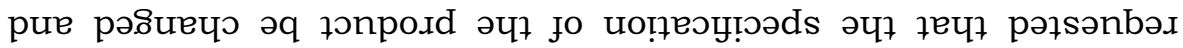

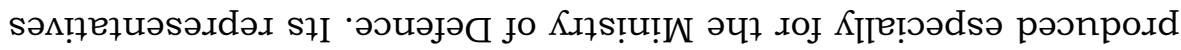

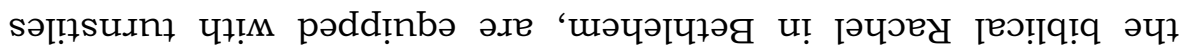

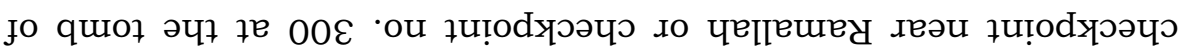

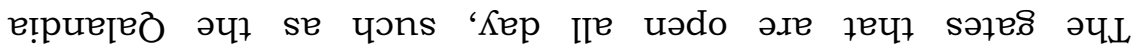

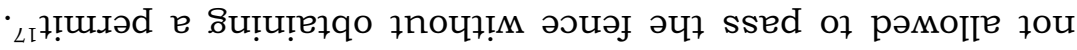

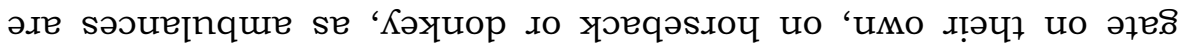

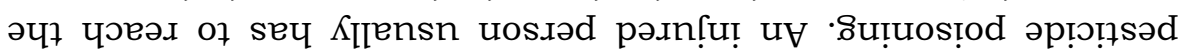

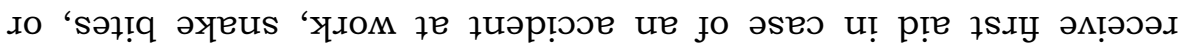

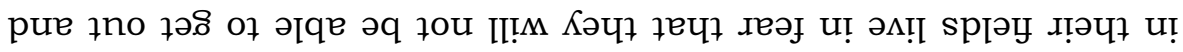

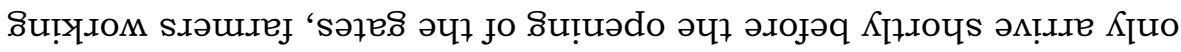

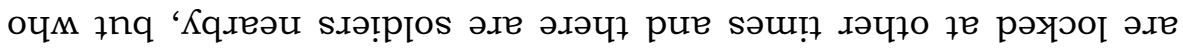

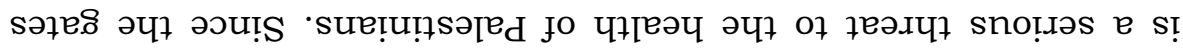

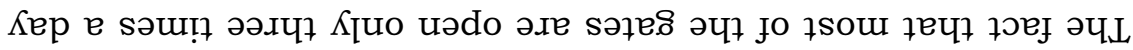

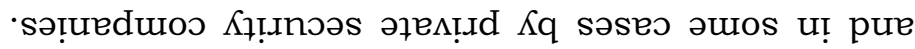

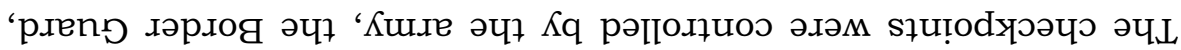


requires displacing of 48,000 cubic metres of earth and rocks, as well as 5,400 cubic metres of backfill, and is paved with 4,500 square metres of asphalt. For every kilometre, there are about 190 concrete poles holding up approximately 25 detection lights, 1,400 square metres of fencing and 8 kilometres of barbed wire ${ }^{20}$.

Not without reason did General Yaron admit that 'It is a project which from the engineering perspective is the greatest that Israel has known. Each day, more than 500 pieces of heavy machinery move and transport millions of cubic metres of earth. Each kilometre costs around 10 million shekels. That's about 2 million dollars per kilometre. ${ }^{21}$, The scale of the project and its cost indicate that Israel does not think of the wall as a transitional solution ${ }^{22}$. Ironically, the entire investment takes place with the involvement of the Palestinian labour force, which is much cheaper than its Israeli counterpart. With no prospect of any other employment, Palestinians build the wall around their villages ${ }^{23}$.

The fact is that the number of attacks carried out in Israel started to fall significantly after the construction of the wall had begun; however, there is no clear evidence that this was the reason of this investment ${ }^{24}$. The decision of the Palestinian factions to stop their brutal practice, as well as the effective operation of Israeli intelligence, which detected planned attacks in time, may

$\mathrm{km}$ expected in 2002, when the project started, to 15 million shekels per $\mathrm{km}$ in February 2004. Amos Harel, Security Sources: cost of fence could rise to NIS 15 M per km, „Ha'aretz”, 23 II 2004.

${ }^{20}$ R. Backman, A Wall in Palestine, Picador, New York, 2006, pp. 65-66.

${ }^{21}$ Wall, directed by Simon Bitton, France-Israel, 2004.

${ }^{22}$ The cost of building a fence around the Gaza Strip was much lower due to it being a small area - only $50 \mathrm{~km}$ - and having flat topography. The barrier around the Gaza Strip has been built along the former demarcation line so it does not separate Palestinians from their lands.

${ }^{23}$ Wall, directed by Simon Bitton, France-Israel, 2004.

${ }^{24}$ The website of the Ministry of Foreign Affairs of Israel provides no current data, but it indicates a $30 \%$ drop in the number of terrorist attacks that took place in 2003 compared to 2002. The drop was recorded in the northern West Bank, where the construction of the barrier had already begun, and not in the south, where the wall was at the planning stage. Israel, the Conflict and Peace: Answers to frequently asked questions, Nov. 1 2007, http:// mfa.gov.il/MFA/ForeignPolicy/FAQ/Pages/Israel-\%20the\%20Conflict\%20and\%20Peace$\% 20$ Answers $\% 20$ to $\% 20$ Frequen.aspx 
have been more important. Furthermore, the wall could not have reduced the number of attacks as only slightly more than $60 \%$ of its structure was completed by 2016, meaning that it became only more difficult, but not impossible to enter Israel. Nevertheless, the official propaganda of the Israeli authorities maintain that it is the wall that prevented the attacks, thus giving ordinary Israelis, who do not analyse the situation more deeply, a sense of being protected by the state. By building the barrier, Israel has strengthened the sense of security among its citizens. It has created the impression of law and order, which is regarded as the fundamental task of architecture.

The wall has also led to the mental separation of Israelis from the problems of the Palestinians living in the West Bank and has strengthened the feeling of remoteness and indifference to their fate. This problem has been perfectly presented in the film Checkpoint, directed by Yoav Shamir. It was shot between 2001 and 2003, when it was particularly traumatic for the Palestinians to pass through the checkpoints due to the ongoing Second Intifada. The film shows how Palestinians are treated and how the control imposed on them impedes their daily life. The film also shows the behaviour of Israeli soldiers. The director encourages the viewer to reflect on the attitude of these young people whose minds are undoubtedly affected by the situation. In the 2004 interview for 'Documentary Film Quarterly', Yoav Shamir said: 'Everybody is like a victim; the soldiers, the Palestinians. I want to show what effects the occupation has on the Palestinians but even more what the effects are on society ${ }^{25}$.

The story of Abdel Rahman Haj Ibrahim, a Palestinian professor at Bir Zeit University in Ramallah who spent many years in Poland, says a great deal about the divisions that have been deepened by the wall in the minds of the two peoples:

\footnotetext{
${ }^{25}$ Interview, "Documentary Film Quarterly", Issue 52, 2004 14-15, "Purposeful Film Making".
} 
We do not exist for them. I will give you a hint to understand how they see us. Gilo is partially located on the lands of Beit Jala. They wanted to build a Wall after the Intifada. Okay, they built the Wall between Beit Jala and Gilo. The settlers were protesting - the Wall is ugly, do something with this Wall, it is just terrible, it is very ugly, depressing, we are depressed by looking at this Wall. Okay, they drew on the Wall what was visible when the Wall was being erected. The same landscape that was seen before is now on the Wall. But the drawing contains a tragic allusion. There is a house, a tree, a donkey, a cow or a sheep, but there is no man. There is no Palestinian, there are no people. Do you understand? They do not see $u^{26}$.

The second dimension of the wall is that instead of establishing law and order, it leads to the existence of their opposites - chaos and mess, mixed with a sense of loss of hope for a better tomorrow. The Palestinians are aware of the fact that the barrier is a long-term construction, which deepens their sense of hopelessness. The experience of Palestinians living on the other side has been shown in the film Wall, directed by Simon Bitton. It was shot near the Jewish settlement of Gilo close to Bethlehem and the Palestinian town of Qalqilya ${ }^{27}$. Bitton's team filmed at the time when the wall was being erected. The film highlights the solidity of the wall and draws attention to the weight of the cement from which it has been created. Even when the director is talking to people, the camera remains focused on the wall to show the extent to which it is present in their lives. For the young generation of Palestinians, it has become a permanent part of every dimension of their surrounding reality.

The Palestinian economy suffered greatly due to the construction of the wall. It has raised the cost of business even more and seriously disrupted the predictability that is necessary for a stable economic development. As pointed out by experts of the World Bank, the United Nations Conference on Trade and Development (UNCTAD) and the International Monetary Fund, the restrictions

${ }^{26}$ The author's interview with Abdel Rahman Haj Ibrahim, 31 August 2015.

${ }^{27}$ Wall, directed by Simon Bitton, France-Israel, 2004. 
that have been imposed by the occupants, including the wall, are a major constraint on the sustainable development of the Palestinian economy.

A weak point in the economy is the high unemployment rate as the inhabitants of the West Bank and Gaza have lost employment opportunities in Israel. The number of Palestinians from the occupied territories working in Israel and settlements is continually decreasing ${ }^{28}$. According to the Palestinian Central Bureau of Statistics, in the second quarter of 2012, there were 22,500 Palestinians employed in Israel and Israeli settlements without the required permit ${ }^{29}$. In addition, it is estimated that despite the presence of the barrier, at least 14,000 Palestinians smuggle themselves into Israel every day to look for employment and, subject to only slight fluctuations in the coming years, this number can be considered a constant ${ }^{30}$. According to data from late 2016, almost a quarter of Palestinians from the West Bank, not including East Jerusalem, are considered to be food-insecure and dependent on food aid from international organizations ${ }^{31}$.

Abeer Alkhateeb, a civil resistance activist working in Ramallah, says that when journalists ask her about the condition of the Palestinian society, she always replies in the same way:

Go to the street and look in their eyes. Of course, they're tired. We are West Bank, we live in a box, small box, everything closed, no job, no works. The life, it's so much expensive. So much expensive. There's

\footnotetext{
${ }^{28}$ There were 180,000 Palestinians in 1987, 110,000 in 2000 and this number decreased to only 68,000 in 2007. Saree Makdisi, Palestine inside Out: An everyday Occupation, NY, London 2010, p. 157.

${ }^{29}$ West Bank Movement and Access Update, United Nations Office for the Coordination of Humanitarian Affairs occupied Palestinian territory, Special Focus September 2012, p. 9 http://www.ochaopt.org/documents/ocha_opt_movement_and_access_report_september_ 2012_english.pdf

${ }^{30}$ United Nations Office for the Coordination of Humanitarian Affairs Occupied Palestinian Territory the Humanitarian Impact of the Barrier, July 2013, p. 1, http://www.ochaopt.org/ documents/ocha_opt_Barrier_factsheet_july_2013_english.pdf

${ }^{31}$ Humanitarian Response Plan 2017, United Nations Office for the Coordination of Humanitarian Affairs, OCHA, Dec. 2016, http://www.ochaopt.org/content/2017humanitarian-response-plan-occupied-palestinian-territory
} 
no money, come to get the money back, so, of course, they're tired. Of course, they need their life ${ }^{32}$.

Tourism is an important sector of the Palestinian economy that has been adversely affected by the fence and other restrictions imposed by Israel. It is clearly seen given the potential of the West Bank, which has many places of religious, historical and environmental significance. According to reports of the World Bank, this area is unique in terms of the different tourist and recreational activities ${ }^{33}$.

This has been well described in a book Palestinian Walks by Raja Shehadeh, a Palestinian writer and lawyer famous for his passion for hiking:

How unaware many trekkers around the world are of what a luxury it is to be able to walk in the land they love without anger, fear or insecurity, just to be able to walk without political arguments running obsessively through their heads, without the fear of losing what they've come to love, without the anxiety that they will be deprived of the right to enjoy it. Simply to walk and savour what nature has to offer, as I was once able to $\mathrm{do}^{34}$.

Restrictions in this area also affect foreigners. Travel agencies in Israel do not provide access to many places in the West Bank, such as Sabastia near Nablus, an ancient Roman city which, according to some accounts, is the burial place of John the Baptist. Tourists also find it difficult to reach St George's Church in Burqin near Jenin, which is one of the oldest churches in the world. It was erected at the place where, according to the Gospel of Saint Luke, Jesus healed lepers ${ }^{35}$. As noted by Stephen Sizer, a British

\footnotetext{
${ }^{32}$ The author's interview with Abeer Alkhateeb, 31 August 2015.

${ }^{33}$ The economic costs of the Israeli occupation of the occupied Palestinian territory. A bulletin published by the Palestinian Ministry of National Economy in cooperation with the Applied Research Institute-Jerusalem (ARIJ), September 2011, The Ministry of National Economy, p. 29, http://www.un.org/depts/dpa/qpal/docs/2012Cairo/p2\%20jad\%20isaac\%20e.pdf ${ }^{34}$ R. Shehadeh, Palestinian Walks: Notes on a Vanishing Landscape, London: Profile Books, 2008, p. 33.

${ }^{35}$ Forbidden Pilgrimage, directed by Ahman Damen, 2013.
} 
writer and commentator, Israeli authorities consider Palestinian guides to be particularly dangerous. This was confirmed by the statement of the first Israeli Prime Minister David Ben-Gurion, who said that he would prefer a Palestinian to be a pilot than a tourist guide. In his view, a Palestinian guide may in fact cause more harm to Israel than a bomber pilot ${ }^{36}$.

One of the biggest blows inflicted on the Palestinian economy by Israeli architects was the separation of Palestinian towns and villages from East Jerusalem through the construction of a section of the wall called the Jerusalem envelope because of its sinuous shape. This led to serious economic and social consequences. East Jerusalem was the political, commercial, cultural and religious centre for the whole Palestinian population from the West Bank and the Gaza Strip ${ }^{37}$. It was the commercial heart of Palestinian life. Most of the projects in Jerusalem depended on supplies from the West Bank. Many shops and factories in Jerusalem employed workers from villages situated around Jerusalem. Although many of their inhabitants were not permitted to work in Jerusalem, they regularly penetrated the city.

Qalqilya with 60,000 residents is an example of a Palestinian city whose development was abruptly halted by the construction of the wall in September 2003. It is located in the northern part of the West Bank on fertile land rich in water resources. As a result, the city was a centre of agriculture, sales and service ${ }^{38}$. Qalqilya served 32 surrounding villages and towns, with a total population of 40,000 to 50,000 people. Many of these residents were employed in the Israeli labour market. The Israelis also had access to cheaper goods and services coming from there.

\footnotetext{
36 Ibidem.

${ }^{37} 10$ Years since the International Court of Justice (ICJ) Advisory Opinion 9 July 2014, OCHA, p. 7, http://www.ochaopt.org/documents/ocha_opt_10_years_Barrier_report_english.pdf (10 V 2016).

${ }_{38}$ The city is located near Tel Aviv. Many Jewish people began to settle there due to the surrounding fertile lands and water resources. By 2000, 19 settlements were founded there with 50,000 people, representing at that time $25 \%$ of all settlers in the West Bank.
} 
After the city had been surrounded by the wall on three sides (in this area, the fence has a labyrinthine shape similar to the Jerusalem envelope), the unemployment rate soared to $75 \%$, and one-third of outlets were closed. Some 4,000 of 43,000 residents of Qalqilya resettled in other cities in the West Bank. After the construction of the wall, 500 out of 600 hectares of arable land and one-third of the water supply to the city were seized. From October 2003, access to farmland and water in the surrounding area was subject to the permit regime. Applications for permits were regularly rejected, which led to a decline in agricultural production and to the deterioration of the farmland which could no longer be cultivated. Permits were denied to landless workers who had previously been hired for work.

The Qalqilya district is not an exception. According to the World Bank, the closing of Palestinian villages and towns has had a disastrous impact on agriculture. In 2011, the Office of Coordination of Humanitarian Affairs (OCHA) estimated that about 150 Palestinian communities in the West Bank were separated from their land by the barrier, forcing their owners to apply for special permits and advance notice to access $\mathrm{it}^{39}$. One example is the village of al-Ras, where $90 \%$ of the land is on the other side of the wall. In February 2005, local farmers submitted 120 applications for permission to cross the wall and cultivate their fields. Until April of that year, only seven of them - only the elderly - received permits. In June three more permits were given to children between 10 and 15 years of age. The applications of their parents were rejected. Between June and September, only one other person received a permit. Only one-third of the 180 applications submitted in late summer at the time of the olive harvest were considered positively ${ }^{40}$.

\footnotetext{
${ }^{39}$ United Nations Office for the Coordination of Humanitarian Affairs occupied Palestinian territory, Humanitarian Atlas, December 2011, p. 26, https://www.ochaopt.org/documents/ ocha_opt_humaitarian_atlas_dec_2012_web.pdf

${ }^{40}$ S. Makdisi, Palestine inside Out; An everyday Occupation, NY, London 2010, p. 21.
} 
The state of Palestinian agriculture has been aptly described by a villager Nabi Saleh Bassem Tamimi:

Palestine is..., economy is agriculture economy. This is through... the Israeli destroy the Palestinian economy and make it dependent economy, through for example... Before they live from the land and they grow everything, weed, vegetables, olive trees, ...they have their sheep, the animal etc. After the occupation in 1967, they open the job and the work in the Israeli industry. For that and they give high salary for the Palestinian labour, they bring the busses to the West Bank and they take them inside. This make the people leave their land. For that, for that their incomes come through the work and the Israeli economy services or for industry or agriculture. They leave their land, they can't compete with the Israeli economy, because it's supported through the government ${ }^{41}$.

According to Tamimi, the wall has broken the man-land relations even more deeply. It is particularly difficult for Palestinian farmers, who believe that the land personifies

the soul that your parents and grandparents left in the land. Part of it comes through the tomato that you grow on your land. For that you have the relation. But now we take the tomato from the supermarket. It's somebody else soul ${ }^{42}$.

Limited access to water is another great problem faced by Palestinians. It has a major impact on their agriculture which requires the supply of large quantities of water due to the climate conditions in the Middle East. The location of water sources was a crucial factor for selecting sites for the development of the Palestinian villages and later Jewish settlements, and finally for building the wall. Eyal Weizman, an Israeli architect, openly stated that 'one of the most crucial battlegrounds of the Israeli-Palestinian conflict is below the surface. About 80 per cent of the mountain aquifer is located under the West Bank. ${ }^{43}$

\footnotetext{
${ }^{41}$ The author's interview with Bassem Tamimi, 20 August 2015.

42 Ibidem.

${ }^{43}$ E. Weizman, Hollow Land; Israel's Architecture of Occupation, Verso, London - New York, 2007, p. 19.
} 
The wall encroached on the West Bank, seizing precious water reserves east of the Green Line. Clemens Messerschmid, a hydrologist from the German Cooperation Agency in Ramallah, examined the impact of the barrier on the consumption of water reserves. According to him, the Palestinians in the north-western part of the West Bank have lost some 100 water wells, to which access is limited by the wall. However, the situation is far worse as the most promising areas for drilling new wells are located in this territory. It is estimated that the Palestinians lost three-quarters of available water resources due to the fence.

The education system is another sector that has been affected by the Israeli restrictions for decades. The architecture of separation has only deepened the problem. The Palestinian human rights organization Al-Haq said bluntly:

Israeli occupation threatens the education of new generations of Palestinians living in the Occupied Palestinian Territories (OPT) and consequently endangers the future of a people. The problem is deepened by the fact that more than half of the Palestinian population is less than 18 years old ${ }^{44}$.

Several studies conducted in the late 2000s show that Palestinians attach great importance to education and consider it important for the development of society ${ }^{45}$. According to these studies, schools play a crucial role in the lives of Palestinian children. Nevertheless, both parents and teachers are concerned about the progressive inability of children to concentrate during

\footnotetext{
${ }^{44}$ Al-Haq, International Law in the Shadow of Israeli Occupation, April 12, 2005. As quoted in: Mai Abdul Rahman, Impact of the Israeli Occupation on Palestinian Education, Presented at the 18th Annual Conference of the Global Awareness Society International - May 2009 p. 1, http://orgs.bloomu.edu/gasi/pdf_documents/2009_Proceedings_pdfs/RahmanImpac t\%20of\%20the\%20Israeli\%20Occupation\%20on\%20Palestinian\%20Education\%20for\%20G SIA.pdf

${ }^{45}$ Mai Abdul Rahman, Impact of the Israeli Occupation on Palestinian Education, Presented at the 18th Annual Conference of the Global Awareness Society International - May 2009 1, p. $3 \mathrm{http}$ // organizations.bloomu.edu/gasi/2009\%20Proceedings\%20PDFs/RahmanImpact $\% 20$ of $\% 20$ the $\% 2$ Israeli\%20Occupation $\% 20$ on $\% 2$ Palestinian $\% 20$ Education $\% 20$ for $\% 20$ GS IA.pdf
} 
lessons in the classroom and about the increasing number of absences caused by a sense of insecurity; children themselves still greatly appreciate their education ${ }^{46}$. This can be illustrated by the statement of a teenager, Iddeen Alaa, according to whom the wall not only separates the West Bank geographically, but also separates them socially and culturally, and they must oppose it through education ${ }^{47}$.

Younger students are also aware of how the wall limits their life opportunities, including access to education. In November 2003, Save the Children UK carried out research with children in three schools in Azzun Atmeh, Ras Atiyeh and A-Ras in the Qalqilya district. This showed that the children are well aware of the rights that they are theoretically entitled to and that the fence is not only a physical barrier. The most common words they used to describe the wall was 'a prison'. One child described it as 'a snake that spreads its poison' ${ }^{48}$.

It is difficult to estimate the impact the wall has on children, many of whom have experienced or witnessed violence at checkpoints. Some $90 \%$ of parents declared traumatic behaviour in their children, such as drops in concentration, bedwetting, nightmares and increased aggression ${ }^{49}$. The founder of the Al Rowwad Cultural and Theatre Training Centre in the Aida refugee camp, Abdelfattat Abusrour, who works with children on a daily basis, observed:

\footnotetext{
${ }^{46}$ The conclusions can be found in the report of Save the Children - Save the Children Alliance, Report "Palestine: The education of children at risk" presented to the 57th Session of the UN Commission on Human Rights, March 2001. http://www.forcedmigration.org/ psychosocial/inventory/psychosocial-working-group-inventory-of-key-resources / pwg007/ pwg007.pdf

${ }^{47}$ Cf. Students Under Occupation Take a Stand, photographs from the Right to Education Photography Project, Birzeit University, Ramallah 2006, p. 54.

${ }^{48}$ Save the Children UK and SAVE the Children Sweden, Living behind Barriers: Palestinian Children Speak Out, a paper presented to the UN Commission on Human Rights, March 2004, p. 10.

${ }^{49}$ Cairo Arafat, A Psychosocial Assessment of Palestinian Children, July 2003, pp. 5-6, https://unispal.un.org/DPA/DPR/unispal.nsf/3d14c9e5cdaa296d85256cbf005aa3eb/ 6bb117b13425504685256ea90055c8ab/\$FILE/assessment.pdf
} 
The system of occupation affects the relationship between these young people and their families or those who are supposed to protect them or fail to do that. When a young man, an adolescent see his mother or his father humiliated by $18,19,20$ or 40 -year old soldiers, they cannot protect their own house, they cannot protect their own family, they cannot satisfy the needs of their family, financially or otherwise, because of the high percentage of unemployment or even though if they have salaries, they cannot... sometimes they are not having the salary every month or they work with the Palestinian authority and so on.... as well, so there is this also fragile situation within the family itself that the father who is the highly respected, the feeder of the family, the man who responds to the needs of the family is not more in fulfilling the situation, his position. The mother a lot of times taking the leading role even despite her husband, trying to work and anything or whatever. The absence of parent sometimes, because of this work or because of imprisonment or because of travelling outside the country, so there's a kind of gap between the family, the parents and the children ${ }^{50}$.

The wall has also limited the access of Palestinian students to higher education. The section of the wall in Abu Dis bordering East Jerusalem has been built on the Al-Quds University campus. Teachers and students who live in East Jerusalem are therefore forced to take a 90-minute commute, almost to Jericho, to reach the campus, whereas it took them 10 minutes in the past ${ }^{51}$. For some time, when the wall was still unfinished, people would pass it through gaps. In the initial version of the plan, the university, situated to the east of Jerusalem, was to be divided by the wall into two parts. The plan was corrected after the personal intervention of Sari Nusseibah, the then president of Al-Quds University. Thus, he is among the few Palestinians whose personal efforts resulted in changing the course of the wall.

The wall is also detrimental to health of Palestinians living in the West Bank, particularly patients who require specialist treatment or chronic care. Specialist care for Palestinians is available in

\footnotetext{
50 The author's interview with Abdelfattat Abusrour, 26 August 2015.

${ }^{51}$ Gary Fields, Ex-Communicated: Historical Reflections on Enclosure Landscapes in Palestine, Radical History Review. Fall 2010, Issue 108, p. 147.
} 
only six hospitals in East Jerusalem which offer procedures, such as dialysis, cancer treatment, open-heart surgery, eye surgery, neurosurgery and physical therapy for children ${ }^{52}$. No hospital in the West Bank can perform such procedures. Obtaining a permit to access treatment in East Jerusalem is a long and stressful process. The patient's physician has to submit a request to a relevant department of the Palestinian Ministry of Health, the hospital and the Israeli Civil Administration. Males aged between 15 and 30 often have their requests for permits turned down on the grounds of security. Permits are also invalid during periods of general closure announced by the military for security reasons and on Israeli holidays. Furthermore, permits are often granted for shorter periods than the treatment requires. In such cases, the patient must go through the same procedure again.

Palestinians requiring medical attention are further impeded by the fact that cars with a Palestinian registration address cannot enter the East Jerusalem area, and patients must pass through the checkpoints on foot, which often takes up to two hours ${ }^{53}$. Disabled children on crutches or in wheelchairs who need to go to a hospital in Jerusalem for treatment have problems passing through metal detectors. It is difficult for parents of children who need dialysis to receive permits ${ }^{54}$.

Ambulance transfer to hospitals in Jerusalem can also be difficult. In 2011 , only $5 \%$ of ambulances belonging to the Palestinian Red Crescent were allowed to pass through checkpoints ${ }^{55}$. All the other

\footnotetext{
${ }^{52}$ United Nations, World Health Organization, Special Focus, July 2010, The Impact of the Barrier on Health, p. 9, https://www.ochaopt.org/documents/ocha_opt_special_focus_july_ 2010_english.pdf

${ }^{53}$ United Nations, World Health Organization, Special Focus, July 2010, The Impact of the Barrier on Health, p. 10, https://www.ochaopt.org/documents/ocha_opt_special_focus_ july_2010_english.pdf

${ }_{54}$ West Bank Movement and Access Update, United Nations Office for the Coordination of Humanitarian Affairs occupied Palestinian territory, Special Focus September 2012, p. 15, http://www.ochaopt.org/documents/ocha_opt_movement_and_access_report_september_ 2012_english.pdf

${ }^{55}$ Only $9 \%$ of ambulances were allowed to cross the barrier in the following year.
} 
ambulances had to drop off patients at the wall to be transferred to ambulances with Israeli licence plates ${ }^{56}$.

These challenges can often lead to dramatic situations. One was described by Fiad Jala, a Palestinian living in the area between Jerusalem and Beit Jala. This is how he recalls his mother's death:

Our situation becomes particularly difficult in the case of medical emergency. In 2005, my mother had a heart attack. We called the Palestinian Red Crescent Society stationed in Bethlehem, but they told us they needed to coordinate with the Israeli authorities in order to be able to cross into Jerusalem. There was no time for that, so we tried to call Magen David Adom, the Israeli emergency care provider. However, Israeli ambulances could not access the area either because - they told us - this is a military area. At that time, there was a gap in the Wall, just before the checkpoint. It was around a kilometre from my home. I carried my mother through the fields and we went through the gap in the Wall. Once we crossed, she died in my arms ${ }^{57}$.

The wall has also separated Palestinians from their places of worship. The Palestinian Christians from the West Bank cannot freely enter the Basilica of the Holy Sepulchre and the Muslims are not allowed to freely visit the al-Aqsa mosque in Jerusalem. They cannot visit their families living in East Jerusalem and the Gaza Strip during Ramadan. Israel put these restrictions in place for safety reasons, but it sometimes relaxes the permit regime on holidays and allows more Palestinians to pass through the barrier.

All these examples show that the wall has undoubtedly had a fundamental impact on the rhythm of life in the West Bank.

\footnotetext{
${ }^{56}$ Health conditions in the occupied Palestinian territory, including east Jerusalem, and in the occupied Syrian Golan, World Health Organization, Sixty-sixth World Health Assembly A66/INF./ 1 Provisional agenda item 2016 May 2013, Annex, The State of Palestine Ministry of Health, A report on the health conditions in the occupied Palestinian territory, Sixty-sixth World Health Assembly, March 2013, p. 14, http://apps.who.int/gb/ebwha/pdf_ files/WHA66/A66_INF1-en.pdf

${ }^{57}$ Barrier Update, Special Focus, July 2011, OCHA, p. 18, http://www.ochaopt.org/ documents/ocha_opt_Barrier_update_july_2011_english.pdf
} 
In the introduction to the publication about Israeli activities, Amira Hass, a famous 'Haaretz' correspondent from the Machsom Watch organization, writes:

Land can eventually be returned but the endless waiting at checkpoints, the vain wait for a permit, the long and exhausting bypass routes, the renunciation of simply moving from place to place, are all lost time that can never be regained. Time is a fundamental human resource, whether it is used for studies, work, family outing, voluntary idleness or travel. Day by day Israel's closure policy robs 3.5 million human beings of that precious resource, from each one individually, each a world unto themselves, and from the collective as a whole. With time, they are also robbed of the right to plan their lives. How can you plan when you don't know if you will wait at the checkpoint for one hour or four, if you will encounter three checkpoints or only two, if the permit will arrive or not? They are robbed of the right to spontaneity ${ }^{58}$.

It is estimated that half a million Palestinians are significantly affected by the wall on a daily basis. This number consists of some 250,000 people who live in enclaves partially or almost completely surrounded by the barrier, and another 225,000 living in East Jerusalem. However, the construction of the wall particularly affects 30,000 Palestinians who have remained on the Israeli side of the fence after Israel seized part of the West Bank territory. The space between the barrier and the Green Line has been declared a closed military zone. This means that the Palestinians over 16 years of age who live there must apply to the civil administration for special permits for permanent residency in their homes and resident status. Restrictions also affect the transport of goods from the West Bank. Only vehicles with special permits can go to the other side of the fence. They can each carry only two pallets of goods no higher than 1.2 metres $^{59}$. Drivers unload them at the checkpoint for inspection. Construction materials such as cement

\footnotetext{
${ }^{58}$ Foreword by Amira Hass, [in:] Yehudit Kirstein Keshet, Checkpoint Watch; Testimonies from Occupied Palestine, New York: Zedbooks, 2006, p. XV.

${ }_{59}$ West Bank Movement and Access Update, United Nations Office for the Coordination of Humanitarian Affairs occupied Palestinian territory, Special Focus September 2012, p. 12,
} 
or sand cannot be transported, so the inhabitants of the area are forced to buy them in Israel. It makes the situation even worse as prices of building materials in Israel are significantly higher than those in the West Bank and most people cannot access the selling points due to their lack of a permit to enter Israel.

One of the enclaves located in the area between the Green Line and the fence is Barta'a, inhabited by 5,000 Palestinians. The West Bank can be accessed from this enclave through the Rekhan checkpoint which is operated between 5 a.m. and 10 or 11 p.m. by a private security company. During the remaining night hours, the checkpoint is closed and in emergency situations it is necessary to apply for a special permit ${ }^{60}$. As a result, pregnant women often leave the enclave one month before delivery for fear of delay at the checkpoint and hindered access of ambulances from Jenin City ${ }^{61}$.

Due to these difficulties, which sometimes turn into human dramas, many Palestinians have a growing sense of limitation, which they think is the goal of the Israeli authorities who want to start a wave of permanent migration from the West Bank. As Rifat Kassis, a human rights activist, says:

The wall limited our areas and by limiting our areas, it limited also our numbers. And I think this would be the most devastating consequence of the wall which people till today they don't speak about it. [...] The wall is limiting our numbers and this would be soon the important pushing factor of people to leave. Because there is no other way out...

\footnotetext{
http://www.ochaopt.org/documents/ocha_opt_movement_and_access_report_september_ 2012_english.pdf

${ }^{60}$ For some time, Barta'a was visited twice a week by a medical team from the UN Programme of UNRWA; however, since September 2007, UNRWA has been unable to access Barta'a and the programmes have been suspended. WHO, The right to health in the occupied Palestinian territory: West Bank and East Jerusalem, August 2009, p. 6. As quoted in: United Nations, World Health Organization, Special Focus, July 2010, The Impact of the Barrier on Health, p. 7, https://www.ochaopt.org/documents/ocha_opt_special_focus_july_2010_english.pdf ${ }^{61}$ West bank Movement and Access Update, United Nations Office for Coordination of Humanitarian Affairs occupied Palestinian territory, Special Focus, September 2012. p. 13, http://www.ochaopt.org/documents/ocha_opt_movement_and_access_report_september_ 2012_english.pdf
} 
No land left. For me this would be the worst scenario and the toughest part of the wall ${ }^{62}$.

Rehab Nazaal, a Palestinian visual artist who also holds a Canadian passport, talks about the prevailing sense of enclosure, especially among young people. In 2015, after 20 years of living in Canada, she resettled in the West Bank. When she left, the West Bank and Israel had not yet been separated, and so going from Bethlehem to Jaffa, Acre and Nazareth by car did not pose any problem. However, as Nazaal says, after returning, she realized that:

This network of walls and checkpoints and hermetic system, exhausting, It's pushing the people out. I mean, the youth cannot stand it. You see, there is actually among the youth, you see this trend. They wanna leave, suffocating. Like I speak to my nephews and nieces, they are studying engineering. Like my nephew, he's telling me: I am suffocating, I cannot breathe. I do have a business, I do make money, I do have a life, I mean economic, but I can't breathe ${ }^{63}$.

Israeli human rights activists have similar opinions. According to the Israeli activist Nina Mayorek, '[the means of controlling] the Palestinian population is to FORBID everything. Palestinians are not allowed to exist. Since this is an impossible situation, Palestinians [cannot help but] constantly trespass every rule ${ }^{64}$.

As a result, Palestinians are less against the idea of a possible reconciliation of the nations. According to a 2008 study conducted by the Friedrich Naumann Foundation for Liberty, $71 \%$ of Palestinians were in favour of reconciliation with Israel, but in 2011 this number dropped to $61 \%{ }^{65}$. The most reluctant group consists of young Palestinians aged 18-24 years, $46 \%$ of whom were in favour of reconciliation. Over this three-year period,

\footnotetext{
${ }^{62}$ The author's interview with Rifat Kassis, 3 September 2015.

${ }^{63}$ The author's interview with Rehab Nazaal, 8 September 2015.

${ }^{64}$ Yehudit Kirstein Keshet, Checkpoint Watch; Testimonies from Occupied Palestine, New York: Zedbooks, 2006, p. 75.

${ }^{65}$ K. Vick, Palestinians, Contained, Time, 12/20/2010, Vol. 176, Issue 25, p. 49.
} 
the number of Palestinians who positively responded to the question of whether they would be able to live next to a Jewish neighbour decreased even more $-50 \%$ in 2008 and only 38\% in 2011. Only one in three young Palestinians considered it to be a possibility. This is due to the fact that the only Jews they meet are soldiers who usually treat them badly.

These data show that a wall made of concrete and barbed wire creates a psychological barrier which is much harder to break down. In the 2010 film Palestinian Window, Anwar Hamed, a novelist and poet, asks if there are not enough barriers? He adds that it will take many years to break down the mental barriers that have been erected since 1948, when the Palestinians were expelled, and those that are still being built today. He says that the Israelis had not had enough of these barriers, so they decided to build another one, which will be very hard to demolish, even if they choose to do so one day. The novelist concludes that "it is easy to break down a concrete wall and the Israeli soldiers who destroy Palestinian houses know this very well. But it will be much more difficult to break down the mental barriers between them" ${ }^{\prime \prime}$.

It is difficult to identify which of the consequences of the erection of the wall in the West Bank are the most acute for its residents. It depends on the perspective. It is likely that the ill would say the difficulty with or even impossibility of travelling to specialist hospitals in East Jerusalem. School-age children and their parents would probably mention the limited access to schools. Palestinian workers hoping to find a better paid job in Israel would mainly complain that they need to illegally sneak through the Green Line. Palestinian farmers would most acutely feel the lack of free access to their fields that are now on the other side of the wall.

Each group experiences the wall differently and with varying intensity. One thing is certain: the analysis of the elements

${ }^{66}$ Cf. Palestinian Window, directed by Eran Torbiner, Palestine/Israel, 2010. 
of spatial and social engineering in the West Bank does not confirm the aforementioned statements of classical and contemporary theorists of architecture, according to whom the essential task of architecture is to introduce law and order into the environment. They do not take into account that architecture can have more than just one dimension. The wall in the West Bank shows that architecture can have multiple meanings.

The most serious and long-lasting effect is possibly the generation of habits that lead to the development of a separatist mentality. This in turn leads to enslavement. As Abdelfattah Abusrour, the founder of the Al Rowwad Cultural and Theatre Training Centre in the Aida refugee camp, puts it:

The most dangerous thing is to get used to oppression, to occupation and facts on the ground continuously create it. When I was a child, I could go everywhere in Palestine, despite the occupation people could drive their car and go to Jaffa, Haifa, wherever. The only two areas which were restricted were the airport and Eilat. Otherwise you could go all over the space. My children are born with wall, so they think it's normal and there's a lot of work to say that it's not normal. People pass checkpoints, these young people, it's sometimes, you feel that they don't even question the presence of the checkpoint, but if it is easy, hopefully it will be easy to pass and not harassment as usual. So it's the brainwashing continuously that is done through the facts on the ground, that is one of the dangerous by-products of this occupation, which make realities or facts on the ground normal. So part of our work is to say that this is not normal and we are under occupation and this is not legitimate in any way and you cannot get used to it ${ }^{67}$.

As the wall generates habits and attitudes desirable to the Israelis, it can therefore be regarded as one of the tools used by those in power to implement the politics and ideology of the state. In this sense, rulers become architects who conduct spatial policy in order to achieve social and political objectives. The materials they use for these purposes - however brutal it may

67 The author's interview with Abdelfattat Abusrour, 26 August 2015. 
sound - are not only concrete, electronic sensors and sand, but also people.

It is time to personalize the hitherto abstract figure of an architect. Let us recall two characters that embody different semantic dimensions of the Israeli architecture. Perhaps it is a twist of fate that they share the same name.

The first is Arieh Sharon. Born in 1900 in Jaroslau, he was the main contributor to the Israeli version of the Bauhaus style. In the 1920s he lived in Dresden where he studied at the famous Bauhaus under Walter Gropius and Hannes Meyer. In 1931 he returned to Tel Aviv where he started building in the Bauhaus style. He began to specialize in hospitals. The Bauhaus style is often considered the quintessence of functionalism in architecture. Its creators assume that it is equally important to recognize the pragmatic, but also the emotional and psychological needs of users, including the environment. According to representatives of this trend in architecture, the planning of space translates into a way of thinking and behaviour. In this sense, an architect becomes not only a designer of buildings, but above all a designer of society. According to the Bauhaus principles, when creating architectural forms, it is necessary to take into account the climate and customs of a local community. The environment should contribute to personal development, which is more important than aesthetics. The Bauhaus theory also assumes that architecture adapted to human needs affects users and in a way educates them. Functionalism breaks with the vocation of architecture, which is to create beautiful objects, but continues to implement other eternal purposes of public architecture, such as usability, convenience and comfort offered to users - the proverbial lack of no draughts, to which Vitruvius once referred.

Sharon's functionalism, with the architecture of Tel Aviv being the best illustration, was meant to develop a community spirit and social harmony among its racially diverse population. For the admirers of this style, Tel Aviv has become a special place 
also thanks to the buildings designed by Arieh Sharon. He was awarded the most important architectural prize in Israel for his contribution to the country's architecture. Just a few weeks after Israel's declaration of independence, Arieh Sharon was entrusted with the task of creating the Government Planning Department ${ }^{68}$.

General Ariel Sharon embodies a completely different, ambiguous dimension of Israeli architecture. He was born in Kfar Malal in 1928. Some call him the King of Israel, others the Butcher of Beirut. He gained his first nickname thanks to spectacular military manoeuvres on the battlefield, so much admired by experts in the art of war. His command and strategic skills brought Israel numerous victories in military campaigns, such as the Six Day War in 1967 and Yom Kippur in 1973. He earned his second nickname after he supported Christian militias, who killed (according to various sources) between several hundred and several thousand civilians, mostly women and children, during the Sabra and Shatila massacre in Beirut in 1982.

Following the end of his military career, General Sharon went into politics and soon became the leading figure of the Israeli right. In the 1990s, he served as Minister of Housing and Construction and was responsible for the development of Jewish settlements in the West Bank. As the Prime Minister between 2001 and 2006, he decided to build a wall around the West Bank, even though initially he had not supported this idea. From that moment, the construction of the barrier became the general's pride and joy. He spent many hours personally overseeing plans and construction progress, monitoring it from the ground and from the air. He became the architect of the biggest spatial investment in Israel's

\footnotetext{
${ }^{68}$ Z. Efrat, The Plan, Drafting the Israeli National Space, [in:] A Civilian Occupation, The Politics of Israeli Architecture, eds Rafi Segal, Eyal Weizman, Tel Aviv, London, New York: Babel, Verso, 2003, pp. 64-65. In 1948, two-thirds of Israel's population lived in three cities: Jerusalem, Tel Aviv and Haifa, and together with the last two cities, $82 \%$ of the Jewish population lived at the Mediterranean Sea. According to Sharon's plan, $45 \%$ of the population would live in metropolises and $55 \%$ in cities and towns.
} 
history, creating a work which for some was exactly what is expected of architecture, i.e. the introduction of law and order in space, which in this case took the form of a sense of security, and for others the opposite - the material source of enslavement and a sense of uncertainty.

In contrast to the tradition of Israeli architecture, developed by Arieh Sharon, the Palestinian Wall, the construction of which was initiated by General Sharon, drastically breaks down the social world instead of merging it into one whole. Its goal - which is emphasized by the Israeli propaganda - is to protect the community of Israel. In fact, however, it is an architectural rape committed against both the social world and the world of nature. While the life of Palestinian settlers has been transformed into the horrendous passage of human masses through dehumanizing turnstiles, violated nature has been grotesquely reduced to the kitschy landscape art covering the Israeli side of the wall. 